\title{
Effect of Groundnut (Arachis hypogaea L.) Haulm and Maize Bran Mixture Supplementation on Growth and Carcass Characteristics Performance of Local Sheep Fed Pasture Hay Basal Diet
}

\author{
Bijiga Tsafiyo ${ }^{1}$, Befikadu Zewdie ${ }^{2,3}$, Hirut Yirga ${ }^{2,3}$, Dejene Teshome ${ }^{4}$ \\ ${ }^{1}$ Benishangul Gumuz Regional, Bureau of Agriculture, Assosa, Ethiopia \\ ${ }^{2}$ Animal Science, Assosa University, Assosa, Ethiopia \\ ${ }^{3}$ School of Range Science, Haramaya University, Haramaya, Ethiopia \\ ${ }^{4}$ Assosa University, Assosa, Ethiopia \\ Email: ×bijigatsafiyo282@gmail.com, zewdienati@gmail.com, abcdetsion@gmail.com,dteshome19@gmail.com
}

How to cite this paper: Tsafiyo, B., Zewdie, B., Yirga, H. and Teshome, D. (2022) Effect of Groundnut (Arachis hypogaea L.) Haulm and Maize Bran Mixture Supplementation on Growth and Carcass Characteristics Performance of Local Sheep Fed Pasture Hay Basal Diet. Open Journal of Animal Sciences, 12, 36-57.

https://doi.org/10.4236/ojas.2022.121003

Received: August 25, 2021

Accepted: November 26, 2021

Published: November 29, 2021

Copyright $\odot 2022$ by author(s) and Scientific Research Publishing Inc. This work is licensed under the Creative Commons Attribution International License (CC BY 4.0).

http://creativecommons.org/licenses/by/4.0/

\begin{abstract}
The experiment was conducted to evaluate the effect of groundnut haulm and maize bran mixture supplementations on feed intake, digestibility, body weight gain and carcass characteristics of local sheep fed hay basal diet at Salga sheep farm in Assosa district, Western Ethiopia. The experiment was laid out in a randomized complete block design (RCBD) with four treatments consisting of six blocks with four animals per block based on their initial body weight of $20.12 \pm 0.05 \mathrm{~kg}$ (mean $\pm \mathrm{SD}$ ). Treatments comprised of feeding natural pasture hay ad libitum $\mathrm{T} 1=0 ; \mathrm{T} 2=100 \%$ maize bran $(\mathrm{MB}) ; \mathrm{T} 3=$ $50 \% \mathrm{MB}$ and $50 \%$ Groundnut haulm $(\mathrm{GNH})$, and $\mathrm{T} 4=100 \% \mathrm{GNH}$. The amount of supplements offered was $300 \mathrm{~g} /$ day/animal on DM basis. The daily feed intake, daily body weight gain, feed conversion efficiency, dry matter and nutrient digestibility, and carcass characteristics parameters were measured during the experimental period. The study result indicates that the crude protein $(\mathrm{CP})$ contents were $7.12 \%$ and $11.6 \%$, and the neutral detergent fiber (NDF) contents were $67.9 \%$ and $57.5 \%$ for natural grass hay and groundnut haulm, respectively. The total DM intake was higher $(\mathrm{P}<0.001)$ in $\mathrm{T} 4(941$ g/day) followed by T3 (937 g/day), and T2 (934 g/day). However, the control group (T1) consumed relatively higher basal dry matter (DM) (767 g/day) as compared to all other groups. Local Sheep supplemented with T4 had significantly different $(\mathrm{P}<0.001)$ FBW (33.2 vs $24.3 \mathrm{~kg})$, FCE $(0.17$ vs 0.08$)$ and ADG (156.2 vs $46.4 \mathrm{~g} /$ day) as compared to the control group. The mean DM,
\end{abstract}


$\mathrm{OM}$, and ADF digestibility in the control group (T1) was significantly lower than the supplemented groups $(\mathrm{P}<0.001)$, but there is no significant difference between supplemented treatments (T2, T3, T4). The CP digestibility was the least in the control group (T1) than the supplemented ( 76 vs $85.5,88.8$ and 89.3 for T1, T2, T3 and T4, respectively). Furthermore, dressing percentage on slaughter weight and empty body weight basis and rib-eye muscle area were high for T4. Empty body weight and hot carcass weight were higher in T4 (27.5 and $15.2 \mathrm{~kg})$ and T3 $(25.5$ and $14.1 \mathrm{~kg})$ as compared to the control group (19.8 and $10.3 \mathrm{~kg}$ ), respectively. Similar to biological performance, the economic analysis also showed that supplementation with T4 resulted in better returns compared to others. Thus, it can be concluded that supplementation in general improved animal performance. Among the supplements, T4 is biologically optimum and economically feasible.

\section{Keywords}

Body Weight, Feed Intake, Groundnut Haulms, Local Sheep, Maize Bran

\section{Introduction}

In Ethiopia sheep is among the major livestock kept across different agro-ecological zones and its population is estimated to be 39.9 million [1]. Among these, about $25 \%-27 \%$ of sheep are found in the lowlands which are arid and semi-arid areas and about $73 \%$ to $75 \%$ are located in the mid and highland areas of the country [2]. The common feature of all production systems used in Ethiopia is mainly the extensive type characterized by small flock sizes and the flock being periodically devastated by poor management. Sheep are playing an important economic role in Ethiopia in the form of meat, milk, skin, hair, horns, manure and religious rituals [3]. Sheep are valuable assets to the local community to whom the small stock is an integral part of the family unit and an emergency source of income [4]. Moreover, in Ethiopia, sheep are the second most important livestock species next to cattle and play an important economic role and make a significant contribution to both domestic and export markets through the provision of food (meat and milk) and non-food (manure, skin and wool) products [5].

Despite the significant contribution to the household and national economy, their productivity is below the expectations as compared to their numbers. Moreover, slow growth rate, high mortality, feed shortage and low productivity are some of challenges of smallholder sheep production in the country. The feed shortage in terms of amount and quality is considered to be the main challenge to increase livestock productivity [6], mainly due to the gradual shrinking of communal pasturelands as a consequence of crop field's expansion [7].

The demand for meat by the increasing human population in Ethiopia may not be easily satisfied and the current high price for the product cannot be maintained with the low level of per capita income [4]. Therefore, development policies in the livestock sector have to look for mechanisms to balance the de- 
mand and supply of meat by improving the productivity of animals. In this regard, sheep by virtue of their small size provide an opportunity to increase meat production, because of their ability to thrive on locally available and low quality and quantity feeds as well as for possessing high reproductive performance.

Extensive sheep production under traditional communal grazing or browsing system is widely practiced in Ethiopia. Natural pastures contribute the major feed resources providing either more than $90 \%$ of the livestock feed in the form of grazing or forage conserved in the form of hay for dry season use. Nevertheless, in Assosa zone, like other parts of the country, pasture grazing is limited by high presence of biting fly and some grazing areas were reserved for natural resource conservation by Benishangul regional government [8]. Although, natural pasture is the main source of feed during all seasons and sheep are supplemented with crop residue during the critical dry season, the natural pastures are markedly declined their nutritional value during the dry season. Similarly, [9] reported that residues from cereal crops are of low nutritive value and are also less consumable.

On the other hand, consumption of low-quality roughages such as straw and poor grass hay can be increased markedly by the addition of protein supplements. Ruminant livestock production is hindered by inadequacy and low quality of feed [10] as well as high level of productivity cannot be obtained since the tropical grasses which are usually given to these livestock are low or deficient in protein [11]. It has however been reported that, when these tropical grasses are supplemented with concentrates, their intake and digestibility are improved [10]. In fact, smallholder livestock farmers rarely adopt such strategies because these farmers consider concentrates as scarce and expensive to use. In order to mitigate the problems associated with the lack of protein supplement, use of crop by-products such as Haulms of higher protein value, straw as animal feed are very important to improve the feed resource base and the use of animal manure as fertilizer is are inputs obtained from animals to increase crop production and productivity.

Groundnut (Arachis hypogaea) and maize are among the food/feed crops widely cultivated in the lowland areas of Ethiopia for various uses including raw materials for oil production, cash income, animal feed, increases soil fertility, serve as good intercrop [12] [13] [14]. Previous sheep fattening experiments conducted by [15] revealed that maize bran is consumed reasonably well by sheep and other classes of livestock. It is relatively cheaper than whole grain and encounters almost no competition for consumption by man. Groundnut haulm served as source of protein for the feed of small ruminant. Groundnut haulms are also having higher value as a feed source for livestock during the long dry season. Concentrate feed sources especially grains and most by-products are expensive and not readily available to farmers. Therefore, it is essential to develop a feeding technology transferable to smallholder farmers by using the local available feeds such as groundnut haulms and maize bran, to improve the livestock productivity and livelihood of smallholder farmers. 
In view of the high cost and less availability of sheep feedstuffs in general and pulse grains and agro-industrial by-products that can serve as a protein supplement in particular, cheap and alternative feed ingredients need to be identified and evaluated. Therefore, it is necessary to look for alternative feedstuffs, which are an easily accessible, cheap, safe and nutritionally adequate substitute for conventional feedstuffs. However, information on the feeding value of groundnut haulms and maize bran in the diets of sheep in Assosa area is lacking. Thus, this study was designed to assess the effect of inclusion of groundnut haulms and maize bran mixtures supplementation in different proportions as an alternative feed ingredient on the performance of local sheep with the following specific objectives.

$>$ To evaluate the effect of groundnut haulms, maize bran and their mixture on feed intake, digestibility, growth performance and carcass characteristics of local sheep fed natural pasture hay-based diet.

To determine the economic profitability of groundnut haulms, maize bran and their mixture supplementation by employing partial budget analysis.

\section{Materials and Methods}

\subsection{Description of the Study Area}

First, confirm that you have the correct template for your paper size. This template has been tailored for output on the custom paper size $(21 \mathrm{~cm} * 28.5 \mathrm{~cm})$. The experiment was conducted at Salga sheep farm in Assosa district, in the Assosa zone of Benishangul Gumuz Regional State, Ethiopia. It is located $673 \mathrm{~km}$ away from capital, Addis Ababa and $12 \mathrm{~km}$ far from the Assosa town. Salga sheep farm is located between $10^{\circ} 05^{\prime} 09.02^{\prime \prime} \mathrm{N}$ latitude and $34^{\circ} 62^{\prime} 33.58^{\prime \prime E}$ longitude. Receives an average rainfall of $950-1000 \mathrm{~mm}$ annually and the average annual temperature is $30^{\circ} \mathrm{C}$ with the hottest season [16]. It is characterized by diverse topography with altitude range of 580 - 1544 m.a.s.l. [17].

\subsection{Experimental Feed Preparation}

Hay from natural pasture was used as a basal diet. The groundnut haulms were obtained from local farmers after harvesting the grain. Groundnut haulms and maize bran were bought from the community and local market. The natural pasture hay was chopped manually to the size of $3-10 \mathrm{~cm}$ so as to improve intake by experimental sheep. Finally, the collected feed was properly dried and then stored in well-ventilated shade until the commencement of the feeding trial.

\subsection{Experimental Design and Dietary Treatments}

The feed ingredient used for experimental animals is presented in Table 1. The experiment was arranged using a Randomized Complete Block Design (RCBD) with four treatments and 6 replications (blocks). Each animal within a block was randomly assigned to one of the four treatment diets. Each animal was offered $300 \mathrm{gm} \mathrm{DM} /$ day of concentrate mix. 
Table 1. The feed ingredients used for experimental animals.

\begin{tabular}{cccc}
\hline \multirow{2}{*}{ Treatments } & Hay & \multicolumn{2}{c}{ Proportions in the concentrate mix } \\
\cline { 3 - 4 } & & Maize bran & Groundnut haulm \\
\hline T1 (control) & Ad libitum & 0 & 0 \\
T2 & Ad libitum & 100 & 0 \\
T3 & Ad libitum & 50 & 50 \\
T4 & Ad libitum & 0 & 100 \\
\hline
\end{tabular}

\subsection{Experimental Animals and Their Management}

Twenty-four yearlings' male Local sheep with milk teeth weighed $20.12 \pm 0.05 \mathrm{~kg}$ were subjected to the experiment. The animals were ear tagged for identification purpose and all animals were drenched with broad spectrum anti-helminthes (Albendazole $300 \mathrm{mg}$ ) prior to the commencement of the experiment. Accordingly, sprayed with Amitraz $12.50 \%$ at Dose of $1.6 \mathrm{ml}$ per 1 Liter of water against internal and external parasite and vaccinated for common diseases of the area (Peste Des Petits Ruminants PPR) prior to the commencement of the experiment.

Basal diet was offered ad libitum at a rate of $20 \%$ refusal. Groundnut haulms and maize bran was weighed and offered two times a day. The supplement feed was provided to individual sheep twice a day at equal portions at 8:00 am and 16:00 pm. Water was available ad libitum to the animals throughout the experimental period. Feeding was continued for the 90 days of recommended standard fattening time.

\subsection{Sampling and Measurements}

\subsubsection{Digestibility and Feeding Trials}

The digestibility trial comprised three days for animals to acclimatize to fecal collecting bags followed by a seven-day feces collection period. Feces were collected every morning for each animal before giving feed or water. Feed offered and refusals were recorded daily throughout the experimental period to determine daily feed intake.

The apparent digestibility of DM and nutrients was calculated as the difference between nutrients intake and that recovered in feces expressed as a proportion of nutrients intake. The energy value of the treatment feeds was also estimated according to [18] as metabolizable energy ( $\left.\mathrm{MJ} / \mathrm{kg} \mathrm{DM}=0.016^{\star} \mathrm{DOMD}\right)$; where $\mathrm{MJ}=$ Metabolizable energy; DOMD = being gram digestible OM intake per kilogram DM. The feeding trial lasts for about 90 days. During this period, feed offered and refused were recorded daily to determine daily feed intake. Thus, DFI of individual sheep was calculated as the difference between the amounts of feed offered and refused $(\mathrm{DFI}=\mathrm{FO}-\mathrm{RF})$; where DFI = daily feed intake, $\mathrm{FO}=$ offered and RF $=$ refused feed. 


\subsubsection{Sampling}

Feces were collected daily from each sheep during the digestibility period. The collected feces were weighed, mixed thoroughly and $20 \%$ was pooled and stored in a deep freezer at $-20^{\circ} \mathrm{C}$ as weekly composite. At the end of the digestibility trial, the composite dried feces of individual animal were thoroughly mixed and sufficient amount of sample for chemical analysis were taken. The partially dried samples were transported to Haramaya University Animal Nutritional Laboratory for analysis. The partially dried samples of feeds and feces were ground using laboratory mill to pass through a 1-mm sieve screen size.

During the feeding trial, feed sample from each feed was taken to determine the nutritive value of each feed. Samples of the hay, groundnut haulms and maize bran offered were taken weekly after thorough mixing and composited for laboratory analysis. Samples of feed offered were taken from batches of feeds and refusals was collected from each animal daily across the experimental period and finally pooled for each treatment and sub-sampled for chemical analysis.

\subsubsection{Body Weight Changes}

Initial body weight of the local sheep was measured at the beginning of the experiment and there after it was taken weekly using the spring weighing balance after overnight fasting, which was done in the morning before the provision of feed and water. The BWC was calculated as the difference between final body weight and initial body weight (BWC = FBW - IBW); where, BWC: Body weight change $(\mathrm{kg}) ; \mathrm{FBW}$ = final body weight and IBW = initial body weight; ADG was calculated as the difference between the initial live weight and final live weight divided by number of experimental days (ADG = IBW - FBW/number of experimental days); where, $\mathrm{ADG}=$ average daily gain (g/day); IBW = initial body weight and FBW = final body weight); while FCE was calculates as the ratio between average daily gain (g/day) to daily dry matter intake $(\mathrm{g})$. (FCE = ADG/DDMI); where, FCE = feed conversion efficiency = ADG average daily gain and Daily Dry Matter Intake = DDMI.

\subsection{Carcass Parameters}

At the end of the feeding trial, all sheep used for experiment were fasted overnight, weighed and slaughtered to determine the effects of treatment feeds on carcass parameters. Immediately before slaughter, slaughter body weight was taken. The animals were killed by severing the jugular vein and the carotid artery with a knife. Blood was collected, weighed and recorded. Skin was properly flayed and weighed. Empty body weight was calculated as the difference between slaughter weight and gut content. The hot carcass weight was estimated after removing weight of the head, thorax, abdominal and pelvic cavity contents as well as legs below the hock and knee joints.

The edible offal components (EOC) namely, blood, liver, kidney, heart, tongue, reticulorumen, omasum-abomasums, small and large intestine, testicles, tail and fats (kidney, heart, omental, scrotal and pelvic) were weighed and recorded 
individually. Total edible offal components (TEOC) were calculated as the total sum of the edible offal components. The non-edible offal components (NEOC), namely, head (without tongue), skin, lung plus trachea, pancreas, spleen, bladder, gall bladder, gut fill, genital organ and feet with hooves were weighed and recorded. Total non-edible offal components (TNEOC) were calculated as the total sum of the non-edible offal components.

The main carcass component was split down at the vertebral column having the two sides as symmetrically as possible and the right parts were stored in a deep freeze over night for properly partitioning the carcass in to bone, muscle and fat. The frozen carcass (right part) was divided in to five main primal cuts carcass components namely: leg, loin, rack, breast and shank and shoulder and neck. The carcass was cut perpendicular to the back bone between the $12^{\text {th }}$ and $13^{\text {th }}$ ribs to measure the cross-sectional area of the rib-eye (longissimus dorsi) muscle area [19]. The rib eye area were traced first on transparency paper then on a graph paper and the area was calculated by counting the squares on graph paper and multiplying with their area after the rib eye area was transferred to graph paper. The five main primal cut carcass components were partitioned to bone, muscle and fat and each part was weighted and recorded. The dressing percentage was calculated as the proportion of hot carcass weight to slaughter and empty body weight.

\subsection{Chemical Analysis}

All representative samples of the daily feed offer and refusals during the feeding and digestibility trial and partially dried fecal samples were ground to pass through $1 \mathrm{~mm}$ screen for the chemical analysis of DM and ash following the procedures of AOAC [20]. The CP was determined by $\mathrm{N}^{\star} 6.25$ and OM was estimated by subtracting ash from 100 . The NDF and acid detergent fiber (ADF) contents for offered and refused feeds and feces samples and Acid Detergent Lignin (ADL) for offered feed samples were analyzed following the procedures of Van Soest and Robertson [21].

\subsection{Partial Budget Analysis}

Partial budget analysis was performed to evaluate the economic advantage of the different treatments by using the procedure of Upton [22]. The partial budget analysis involved the calculation of variable costs and benefits. The selling price of local sheep in each treatment before and after the experiment was considered as total return in the analysis. For the calculation of the variable costs, the expenditures incurred on various feedstuffs were taken into consideration. The cost of the feeds was computed by multiplying the actual feed intake for the whole feeding period with the prevailing market price. The prevailing price of the feeds at the time of feed purchasing including the transportation cost incurred to move them to the experimental site were recorded.

Partial budget method measures profit or loss, which is the difference between 
gains and expenses for the proposed change and includes calculating net return (NR), i.e., the amount of money left when total variable costs (TVC) are subtracted from the total returns (TR):

$$
\mathrm{NR}=\mathrm{TR}-\mathrm{TVC}
$$

Total variable costs included the costs of all inputs that changed due to the change in production technology. The change in net return $(\Delta \mathrm{NR})$ was calculated by the difference between the change in total return $(\Delta \mathrm{TR})$ and the change in total variable cost $(\triangle \mathrm{TVC})$, which is to be used as a reference criterion for decision on the adoption of a new technology.

$$
\Delta \mathrm{NR}=\Delta \mathrm{TR}-\Delta \mathrm{TVC}
$$

The marginal rate of return (MRR) measures the increase in net income $(\Delta \mathrm{NR})$ associated with each additional unit of expenditure ( $\Delta \mathrm{TVC})$. This is expressed in percentage as:

$$
\operatorname{MRR} \%=(\Delta \mathrm{NR} / \Delta \mathrm{TVC}) \times 100
$$

\subsection{Statistical Analysis}

The recorded data obtained from feed intake, feed conversion efficiency, DM and nutrient digestibility, carcasse chacteristics were performed with SAS software version 9.4 using the general linear model (GLM) procedure for variance analysis (ANOVA). When F-test declares significant difference, treatment means were compared using Turkey's standard range (HSD) test. The analyzed data was presented using tables. The statistical model for the data analysis was:

$$
Y_{i j}=\mu+\tau_{i}+\beta_{j}+\varepsilon_{i j},
$$

where: $Y_{i j}=$ response variable (Feed intake, Feed conversion efficiency, DM and nutrient digestibility, carcasse chacteristics);

$$
\begin{aligned}
& \mu=\text { overall mean; } \\
& \tau_{i}=I^{\text {th }} \text { treatment (test diets) effect; } \\
& \beta_{j}=f^{\text {th }} \text { block effect; } \\
& \varepsilon_{i j}=\text { random error. }
\end{aligned}
$$

\section{Results and discussion}

\subsection{Chemical Composition of Experimental Feeds}

The result of the current study indicated that maize bran was lower CP, NDF and ADF content than both natural grass hay and groundnut haulms feeds Table 2. However, groundnut haulms was higher in content than the other supplemental diets. In this study the result of chemical analysis showed that GNH + $\mathrm{MB}$ contained relatively higher $\mathrm{CP}$ and $\mathrm{ADL}$ but it had relatively lower OM than others. On the other hand the natural grass hay refusals in all treatments had lower $\mathrm{CP}$ and higher $\mathrm{NDF}, \mathrm{ADF}$ and $\mathrm{ADL}$ as compared to the natural grass hay offered.

The results of this study indicated that the $\mathrm{CP}$ content of groundnut was higher. This implies that this oil crop straw could serve as a good source of 
Table 2. Chemical composition of feeds and refusals during the experiment.

\begin{tabular}{cccccccc}
\hline \multirow{2}{*}{ Feed offer } & \multicolumn{7}{c}{ Chemical Composition (\% for DM and \% DM for Others) } \\
\cline { 2 - 8 } & DM & Ash & OM & CP & NDF & ADF & ADL \\
\hline Hay & 92.8 & 8.7 & 84.0 & 7.12 & 67.9 & 42.1 & 5.2 \\
Maize bran & 91.4 & 1.5 & 89.9 & 6.8 & 42.6 & 9.1 & 5.2 \\
GH + MB & 91.9 & 4.8 & 87.1 & 10.2 & 53.6 & 16.3 & 10.1 \\
GH & 91.2 & 10.1 & 81.1 & 11.6 & 57.5 & 30.1 & 8.2 \\
\hline Hay (T1) & 92.9 & 9.9 & 82.1 & 6.8 & 72.3 & 39.4 & 9.9 \\
Hay (T2) & 92.8 & 8.1 & 83.8 & 6.1 & 72.7 & 44.9 & 8.2 \\
Hay (T3) & 93.4 & 8.7 & 84.7 & 6.8 & 79.2 & 41.7 & 11.2 \\
Hay (T4) & 93.5 & 8.7 & 84.8 & 6.8 & 72.2 & 45.1 & 12.3 \\
\hline
\end{tabular}

$\mathrm{ADF}=$ Acid detergent fiber; $\mathrm{ADL}=$ Acid detergent lignin; $\mathrm{CP}=$ Crude protein $; \mathrm{DM}=$ Dry matter; NDF = Neutral detergent fiber; $\mathrm{GNH}=$ Groundnut haulms; $\mathrm{MB}=$ Maize bran; $\mathrm{T} 1=0 ; \mathrm{T} 2=100 \% \mathrm{MB} ; \mathrm{T} 3=50 \% \mathrm{MB}$ and $50 \% \mathrm{GNH}$, and $\mathrm{T} 4=100 \% \mathrm{GNH}$.

roughage feed that can provide adequate $\mathrm{CP}$ content $>7 \%$ for proper function of rumen microbes and to meet maintenance requirement of animals [23] [24], given other factors such as lignifications does not limit feed digestibility and nutrient utilization.

The results recorded in the present experiment were comparable with that reported earlier by [25] and [26]. These authors reported that the DM contents of $91.06 \%$ the basal diet such as for natural grass hay. Meanwhile, the CP content of the basal diet was comparable to $7.7 \%$ and $7.9 \%$ CP reported by [26] and [27], respectively. The $\mathrm{CP}$ content of basal diet in the present study was higher than $6.70 \%$ reported by [25]. However, the $\mathrm{CP}$ content of the natural pasture grass hay result obtained in this study was lower than $11.5 \%$ CP reported by [28]. Even though the $\mathrm{CP}$ content of the basal feed, natural grass hay was lower than the other treatment diets as expected, its $\mathrm{CP}$ content was higher than the lower limit of 7\% CP required for optimum rumen function [23]. As a result, the natural grass hay (T1) can be considered as adequate for maintenance requirement of animals in terms of its CP content. As reported by Topps [29], when the CP content of roughages is below 7\%, there will be impaired rumen function resulting in poor digestion of feeds, low DM intake and poor animal performance.

The NDF content of natural grass hay observed in this study was lower than $73.96 \%$ [25] but higher than $62.5 \%$ [30]. The ADF and ADL contents of natural grass hay in the present study were also lower than $48.7 \%$ and $8.5 \%$; and $43.6 \%$ and $18.0 \%$ contents reported by [25] and [30] for natural pasture grass hay, respectively. Higher CP values for maize bran than the current finding $16.9 \%$ and $23.08 \%$ were reported by [31] and [32], respectively but higher in $87.38 \% \mathrm{DM}$, $3.1 \%$ ash, $8.3 \% \mathrm{ADF}$ and $2.2 \% \mathrm{ADL}$ contents of maize bran reported by [33]. According to [34] reported higher CP, comparable OM (90.7\%) and lower NDF 
(52.9\%) contents for groundnut haulm than the current result. The observed variation in maize bran might be due to the effect of processing in milling industries, the variety and the quality of the original grain used in the milling industries. While, the reasons for the difference in the chemical composition of groundnut haulms used in different studies might be due to season, soil fertility and post harvesting management.

\subsection{Dry Matter and Nutrient Intake}

The total and mean daily dry matter intake (DMI) has no significant difference among all treatments except T1. As it indicates in Table 3, sheep in treatment 4 allotted to $100 \%$ GNH trial had best nutrient intake in CP, NDF and ADF with significant difference $(\mathrm{P}<0.001)$ compared to the other treatments. Hence this experiment showed that least feed and nutrient intake was obtained from animals on $\mathrm{T} 1$ treatment.

The mean total dry matter intake (TDMI) was significantly $(\mathrm{P}<0.001)$ higher in T2, T3 and T4 than in T1 which might be due to the higher CP content of the roughage feed confirmed an increase in dry matter intake as the level of crude protein increases in the diet. The daily DM intake (DMI) of the basal diet was lower than T2, T3 and T4. The Lower dry matter intake observed in the control group (T1) might be due to the higher fiber fraction contained in the basal diet, lower dietary $\mathrm{CP}$ intake, and the concomitant lower digestibility of nutrients.

Table 3. Feed intake of local sheep fed on a basal diet of hay and supplemented with groundnut haulms, maize bran and their mix.

\begin{tabular}{ccccccc}
\hline Intake & & & & & \\
Dry matter (g/day) & & T2 & T3 & T4 & SEM & SL \\
\hline Hay & $767.0^{\mathrm{a}}$ & $634.0^{\mathrm{b}}$ & $637.0^{\mathrm{b}}$ & $641.0^{\mathrm{b}}$ & 2.1 & $* * *$ \\
Supplement & 0.0 & 300.0 & 300.0 & 300.0 & 0.2 & \\
Total DMI (g/day) & $767.0^{\mathrm{b}}$ & $934.0^{\mathrm{a}}$ & $937.0^{\mathrm{a}}$ & $941.0^{\mathrm{a}}$ & 2.1 & $* * *$ \\
Total (g/kg BW $\left.{ }^{0.75}\right)$ & $64.8^{\mathrm{d}}$ & $95.8^{\mathrm{c}}$ & $96.5^{\mathrm{b}}$ & $99.1^{\mathrm{a}}$ & 0.2 & $* * *$ \\
Total (\% BW) & $3.3^{*}$ & $2.2^{*}$ & 2.2 & 2.1 & 0.01 & $* * *$ \\
Nutrient Intake & & & & & & \\
OM (g/day) & $517.4^{\mathrm{c}}$ & $792.3^{\mathrm{a}}$ & $789.4^{\mathrm{a}}$ & $775^{\mathrm{b}}$ & 2.3 & $* * *$ \\
CP (g/day) & $41.3^{\mathrm{d}}$ & $63.8^{\mathrm{c}}$ & $73.3^{\mathrm{b}}$ & $88^{\mathrm{a}}$ & 1.8 & $* * *$ \\
NDF (g/day) & $406.0^{\mathrm{d}}$ & $547.3^{\mathrm{c}}$ & $570.1^{\mathrm{b}}$ & $596.7^{\mathrm{a}}$ & 2.1 & $* * *$ \\
ADF (g/day) & $271.8^{\mathrm{d}}$ & $300.1^{\mathrm{c}}$ & $329.1^{\mathrm{b}}$ & $364.5^{\mathrm{a}}$ & 1.1 & $* * *$ \\
ME (MJ/day) & $5.5^{\mathrm{a}}$ & $10.7^{\mathrm{a}}$ & $10.6^{\mathrm{a}}$ & $10.3^{\mathrm{b}}$ & 0.02 & $* * *$ \\
\hline
\end{tabular}

a, b, c, d Means with same letter in the same row are not significantly different; $\left({ }^{* *}\right)=\mathrm{P}<0$. 001; $\mathrm{SL}=$ significance level; $\mathrm{SEM}=$ standard error of the mean; $\mathrm{ME}=$ Metabolizable energy; $\mathrm{MJ}=$ mega joule; $\mathrm{T} 1=0 ; \mathrm{T} 2=100 \% \mathrm{MB} ; \mathrm{T} 3=50 \% \mathrm{MB}$ and $50 \% \mathrm{GNH}$, and $\mathrm{T} 4=$ $100 \% \mathrm{GNH}$. 
Higher intake of DM, OM, CP, and ME for the supplemented group than the control suggests the groundnut haulms had protein potential of the supplements [35] [36] [37].

Local sheep's in the control consumed more DM of hay as compared to the supplemented treatments, because sheep's intake of relatively more hay than the other treatments in order to meet their nutrient requirement. Sheep fed natural grass hay (control, T1) in the current study consumed higher DM than 634, 637 and 641 g/day reported [33] [38] [39], respectively. The higher intake could be due to higher CP intakes representing the advantages of groundnut haulms' supplementation to improve intake of nutrients. In support to this, [3] showed that supplementation of groundnut haulms increased DM and CP intakes.

\subsection{Apparent Dry Matter and Nutrient Digestibility}

The mean apparent digestibility of DM and nutrients in local sheep are given in Table 4. Apparent digestibility of DM had significant difference $(\mathrm{P}<0.001)$ among treatments. The apparent digestibility of $\mathrm{CP}$ was lowest for $\mathrm{T} 1$ and values for T4 were higher than in T3 and T2.

The result showed that the apparent digestibility of DM, OM and ADF was observed to be lower for $\mathrm{T} 1$ than the supplemented groups $(\mathrm{P}<0.001)$. However, there was no difference among the other supplemented groups. In this study, the $\mathrm{CP}$ and NDF digestibility for the control group was lower than for the supplemented groups $(\mathrm{P}<0.001)$ while from the supplemented groups, T2 recorded significantly lower CP and NDF digestibility than the others (T3 and T4). The lower apparent nutrient digestibility in the control group (T1) might be associated with the higher ADF, NDF and ADL content of the basal diet. The significant differences in the apparent digestibility of NDF and ADF among treatments are in agreement with the findings of [40], who concluded that supplementation, had effect on fiber digestibility.

Table 4. Apparent DM and nutrients digestibility (\%) of local sheep fed on hay-based diet and supplement with groundnut haulms and maize bran mix feed.

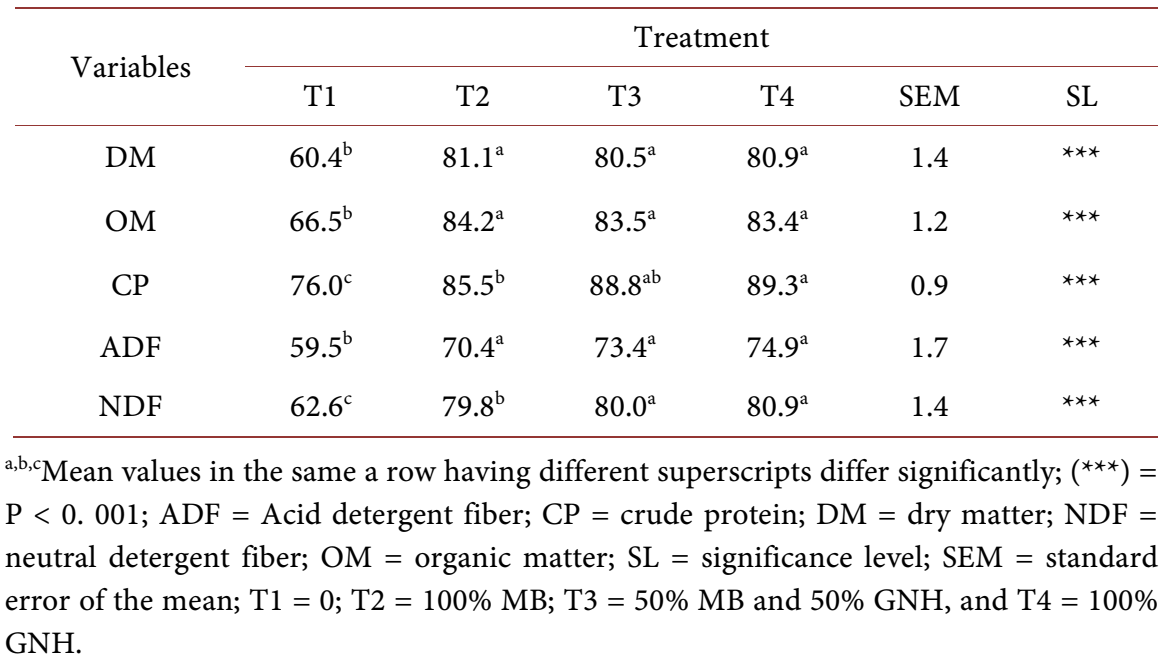




\subsection{Body Weight Change and Feed Conversion Efficiency}

The mean final body weight (FBW), body weight change (BWC), average daily gain (ADG) and feed conversion efficiency (FCE) were significantly higher $(\mathrm{P}<$ 0.001 ) in T4 followed by T3, then T2 and T1 was the least (Table 5). The result showed that sheep supplemented with maize bran and groundnut haulms had significantly higher $(\mathrm{P}<0.001)$ FBW, BWC, ADG and FCE $(\mathrm{T} 4>\mathrm{T} 3>\mathrm{T} 2)$ as compared to sheep fed without supplementation (T1). The final body weights was higher $(\mathrm{P}<0.001)$ in $\mathrm{T} 4$ as compared to all treatment groups. However the variation in the ADG of experimental sheep followed similar trend with the variations in the final weights.

The ADG of sheep fed natural grass hay (T1) result obtained in the present study was higher than reported by [3] and [41] for indigenous sheep. This is generally attributed to the low intake and low $\mathrm{N}$ content of the hay. Feed supplement in T4 was efficient in the utilization of nutrients for sheep live weight gain which is in line with earlier study by [32] reported that a linear increment of feed utilization efficiency with increasing the level of supplementations. According to [42] reported that the nitrogen in groundnut is rapidly degradable in the rumen to meet the requirements of rumen microorganisms for efficient degradation of low quality roughages. This indicated that the ADG increased with the increase in CP contained in the experimental fed. In this study the DM and $\mathrm{CP}$ intake, and also weight gain increased linearly, this might explain CP intake is the main factor determining DM intake and live weight gain. The differences in the FBW and ADG among treatments is attributed to the better protein quality in groundnut haulms that promoted increased DMI and improved feed utilization efficiency of local sheep. Moreover, the feed improved feed conversion efficiency in supplemented groups could be due to high nutrient concentration of the supplement which leads to increased live weight gain [43]. Earlier studies [37] [44] [45] [46] also noted that body weight and carcass characteristics in Washera sheep fed supplemented with graded levels of concentrate mix fed hay as basal diet increased on body weight change and carcass characteristics of sheep.

Table 5. Body weight change, and feed conversion efficiency of local sheep fed on groundnut haulms and maize bran mix supplementation.

\begin{tabular}{ccccccc}
\hline Variables & T1 & T2 & T3 & T4 & SEM & SL \\
\hline IBW (kg) & 20.1 & 20.1 & 20 & 20.1 & 0.1 & NS \\
FBW (kg) & $24^{\mathrm{d}}$ & $29.4^{\mathrm{c}}$ & $31.2^{\mathrm{b}}$ & $33.6^{\mathrm{a}}$ & 0.08 & $* * *$ \\
BWC (kg) & $4^{\mathrm{d}}$ & $9.3^{\mathrm{c}}$ & $11.1^{\mathrm{b}}$ & $14^{\mathrm{a}}$ & 0.06 & $* * *$ \\
ADG (g/day) & $46.4^{\mathrm{d}}$ & $103.2^{\mathrm{c}}$ & $123.7^{\mathrm{b}}$ & $156.2^{\mathrm{a}}$ & 0.6 & $* * *$ \\
FCE & $0.08^{\mathrm{d}}$ & $0.11^{\mathrm{c}}$ & $0.14^{\mathrm{b}}$ & $0.17^{\mathrm{a}}$ & 0.001 & $* * *$ \\
\hline
\end{tabular}




\subsection{Carcass Characteristics}

The average slaughter weight (SW), empty body weight (EBW), dressing percentage, rib eye muscle area, forequarter and hindquarter were significantly $(\mathrm{P}<$ 0.001) higher in sheep supplemented with $300 \mathrm{~g}$ groundnut haulms as compared to sheep supplemented with $300 \mathrm{~g} \mathrm{MB}(50 \%)+\mathrm{GNH}(50 \%), 300 \mathrm{~g}$ maize bran and the control treatment (Table 6).

The dressing percentage on slaughter body weight basis in the current study was higher for sheep supplemented with groundnut haulms (T4), than for T3 and T2; no difference between T3 and T2 but the least for control group (T1). Whereas dressing percentage on the basis of empty body weight was higher for the supplemented sheep than the control. The dressing percentage values on empty body weight basis was higher than on slaughter weight basis, implying the influence of digesta (gut fill) on dressing percentage. In agreement with this study, [47] reported that heavier empty body weight for the supplemented group than the control. Earlier studies [48] [49] also showed that groundnut haulms supplementation of lambs fed on wheat bran had significantly increased slaughter weight, hot carcass weight, and dressing percentage. Similarly, rib-eye muscle area increased for Hararghe Highland sheep fed on concentrate supplementation [47].

\subsection{Edible Offal Components}

The edible offal components of yearling male local sheep fed on natural grass hay based diet and supplement with groundnut haulms and maize bran mix are given in Table 7. Heart, blood, kidney, empty gut, total fat, tongue, ret-rumen, $\mathrm{Om}-\mathrm{ab}$, SI \& LI, testis and tail are considered as edible offal. There was a significant

Table 6. Carcass characteristics of sheep fed on hay-based diet and supplement with groundnut haulms and maize bran mix.

\begin{tabular}{ccccccc}
\hline Variables & T1 & T2 & T3 & T4 & SEM & SL \\
\hline Slaughter weight $(\mathrm{Kg})$ & $24.0^{\mathrm{d}}$ & $29.5^{\mathrm{c}}$ & $31.1^{\mathrm{b}}$ & $33.3^{\mathrm{a}}$ & 0.2 & $* * *$ \\
Empty body weight $(\mathrm{Kg})$ & $19.8^{\mathrm{d}}$ & $24.5^{\mathrm{c}}$ & $25.5^{\mathrm{b}}$ & $27.5^{\mathrm{a}}$ & 0.1 & $* * *$ \\
Hot carcass weight $\mathrm{Kg})$ & $10.3^{\mathrm{d}}$ & $13.6^{\mathrm{c}}$ & $14.1^{\mathrm{b}}$ & $15.2^{\mathrm{a}}$ & 0.04 & $* * *$ \\
Dressing percentage on & & & & & & \\
Slaughter weight base & $42.6^{\mathrm{c}}$ & $46.0^{\mathrm{b}}$ & $45.5^{\mathrm{b}}$ & $47.1^{\mathrm{a}}$ & 0.3 & $* * *$ \\
Empty body weight base & $51.8^{\mathrm{b}}$ & $55.3^{\mathrm{a}}$ & $55.4^{\mathrm{a}}$ & $55.4^{\mathrm{a}}$ & 0.4 & $* * *$ \\
Rib-eye area $\left.(\mathrm{cm})^{2}\right)$ & $9.7^{\mathrm{d}}$ & $11.1^{\mathrm{c}}$ & $11.6^{\mathrm{b}}$ & $12.5^{\mathrm{a}}$ & 0.004 & $* * *$ \\
Forequarter $(\mathrm{kg})$ & $2.6^{\mathrm{d}}$ & $3.0^{\mathrm{c}}$ & $3.1^{\mathrm{b}}$ & $3.4^{\mathrm{a}}$ & 0.01 & $* * *$ \\
Hindquarter $(\mathrm{kg})$ & $3.2^{\mathrm{d}}$ & $3.8^{\mathrm{c}}$ & $3.9^{\mathrm{b}}$ & $4.2^{\mathrm{a}}$ & 0.01 & $* * *$ \\
\hline
\end{tabular}

${ }_{a, b, c, d}$ Means with different superscripts in the same row are significantly different; $\left({ }^{* * *}\right)=\mathrm{P}$ $<0.001$; SEM $=$ standard error of mean; SL $=$ significant level; T1 = 0; T2 $=100 \% \mathrm{MB}$; T3 $=50 \% \mathrm{MB}$ and $50 \% \mathrm{GNH}$, and $\mathrm{T} 4=100 \% \mathrm{GNH}$. 
Table 7. Edible offal components of Local sheep fed on hay based diet and supplement with groundnut haulms and maize bran mix in Assosa district.

\begin{tabular}{|c|c|c|c|c|c|c|}
\hline Parameter & $\mathrm{T} 1$ & $\mathrm{~T} 2$ & $\mathrm{~T} 3$ & $\mathrm{~T} 4$ & SEM & SL \\
\hline Blood (gm) & $1238.0^{\mathrm{d}}$ & $1456.0^{c}$ & $1557.0^{\mathrm{b}}$ & $1625.0^{\mathrm{a}}$ & 1.6 & $* * *$ \\
\hline Liver (gm) & $453.3^{c}$ & $462.3^{\mathrm{b}}$ & $463.3^{\mathrm{b}}$ & $473.2^{\mathrm{a}}$ & 0.4 & $* * *$ \\
\hline Kidney (gm) & $105^{\mathrm{c}}$ & $108.0^{\mathrm{b}}$ & $108.0^{\mathrm{ab}}$ & $109^{\mathrm{a}}$ & 0.2 & $* * *$ \\
\hline Heart (gm) & $115.3^{c}$ & $135.2^{\mathrm{b}}$ & $137.2^{\mathrm{ab}}$ & $138.7^{\mathrm{a}}$ & 0.5 & $* * *$ \\
\hline Tongue (gm) & $65.5^{\mathrm{c}}$ & $66.3^{\mathrm{bc}}$ & $67.0^{\mathrm{b}}$ & $68.2^{\mathrm{a}}$ & 0.2 & $* * *$ \\
\hline Ret-rum (gm) & $620^{\mathrm{d}}$ & $631.0^{c}$ & $636.0^{\mathrm{b}}$ & $647^{\mathrm{a}}$ & 0.5 & $* * *$ \\
\hline Om-ab (gm) & 887 & 890.0 & 893.0 & 898 & 0.8 & NS \\
\hline Empty gut (gm) & $632.7^{\mathrm{d}}$ & $645.2^{c}$ & $646.5^{\mathrm{b}}$ & $662.2^{\mathrm{a}}$ & 1.8 & $* * *$ \\
\hline SI (gm) & $1250.5^{\mathrm{d}}$ & $1264.5^{c}$ & $1277.5^{\mathrm{b}}$ & $1285.8^{\mathrm{a}}$ & 0.6 & $* * *$ \\
\hline LI (gm) & $529.0^{\mathrm{d}}$ & $535.7^{c}$ & $538.5^{\mathrm{b}}$ & $541.2^{\mathrm{a}}$ & 0.97 & $* * *$ \\
\hline Testical (gm) & 264.7 & 265.2 & 333.2 & 268.2 & 33.4 & NS \\
\hline Tail (gm) & $665.3^{c}$ & $673.5^{\mathrm{b}}$ & $674.7^{\mathrm{ab}}$ & $676.7^{\mathrm{a}}$ & 0.5 & $* * *$ \\
\hline Heart fat (gm) & 10.0 & 10.2 & 10.5 & 10.8 & 0.1 & NS \\
\hline Kideneyfat (gm) & 20.5 & 20.3 & 21 & 21.5 & 0.2 & NS \\
\hline Omentalfat (gm) & $79.0^{c}$ & $90.5^{\mathrm{b}}$ & $91.5^{\mathrm{a}}$ & $92.3^{\mathrm{a}}$ & 0.2 & $* * *$ \\
\hline Scrotal fat (gm) & $15.04^{c}$ & $15.1^{\mathrm{b}}$ & $16.2^{\mathrm{b}}$ & $17.0^{\mathrm{a}}$ & 0.06 & $* * *$ \\
\hline Pelvic fat (gm) & $13.02^{c}$ & $13.9^{\mathrm{b}}$ & $14.07^{\mathrm{a}}$ & $15.0^{\mathrm{a}}$ & 0.03 & $* * *$ \\
\hline TEOC $(\mathrm{Kg})$ & $6.10^{c}$ & $7.3^{\mathrm{b}}$ & $7.5^{\mathrm{a}}$ & $7.6^{\mathrm{a}}$ & 0.03 & $* * *$ \\
\hline
\end{tabular}

${ }_{\mathrm{a}, \mathrm{b}, \mathrm{c}, \mathrm{d}}$ Means with different superscripts in the same row are significantly different; $\left({ }^{* * *}\right)=\mathrm{P}$ < 0. 001; NS $=$ Non significant; TEOC $=$ total edible offal component; SL $=$ significant level; $\mathrm{SEM}=$ Standard error of mean; $\mathrm{T} 1=0 ; \mathrm{T} 2=100 \% \mathrm{MB} ; \mathrm{T} 3=50 \% \mathrm{MB}$ and $50 \%$ $\mathrm{GNH}$, and $\mathrm{T} 4=100 \% \mathrm{GNH}$.

difference $(\mathrm{P}<0.001)$ due to supplementation on most of the studied parameters except Om-ab, testical, heart fat and kidney fat $(\mathrm{P}>0.001)$. The weight of blood, empty gut, ret-rumen, small intestine (SI) and large intestine (LI) were significantly $(\mathrm{P}<0.001)$ higher in sheep supplemented with $300 \mathrm{~g}$ groundnut haulms as compared to sheep supplemented with $300 \mathrm{~g} \mathrm{MB}$ (50\%) + GNH (50\%), $300 \mathrm{~g}$ maize bran and the control treatment.

The weight of liver and scrotal fat in the current study was higher for sheep supplemented with groundnut haulms (T4), than for T3 and T2; no difference between T3 and T2 but the least for control group (T1). Whereas kidney, heart, tongues, tail, omental fat, pelvic fat and TEOC were lower for the control treatment than the supplemented. Among the supplemented groups, T2 had significantly lower weight of liver, kidney, heart, tongue and tail than T4; while the weight of omental fat, pelvic fat and TEOC in T2 was lower than in T3 and T4.

In line with the present study, [47] reported relatively lower TEOC which 
were $2.2 \mathrm{~kg}$ for the control and $4.2 \mathrm{~kg}$ for supplemented group. [45] reported higher TEOC, $3605.0 \mathrm{~g}$ for T1 (control) and $6044.0 \mathrm{~g}$ for $45.0 \mathrm{~g} \mathrm{NSC}+200 \mathrm{~g} \mathrm{WB}$ $+100 \mathrm{~g}$ FBH supplemented lambs. [50] reported comparable TEOC, $2.4 \mathrm{~kg}$ for the control and lower TEOC $3.2 \mathrm{~kg}$ for the supplemented. There was a significant difference $(\mathrm{P}<0.001)$ in gut content due to concentrated mix supplementation. The significant difference in gut content between control and supplemented treatment groups in the current study due to similarity in the degradability.

\subsection{Non-Edible Offal Components}

Non-edible offal component of yearling male local sheep fed on hay based diet and supplement with groundnut haulms and maize bran mix are given in Table 8. Head without tongues, penis, skin, lung with trachea, pancreas, full gut, feet and TNEOC significance $(\mathrm{P}<0.001)$ due to supplementation diet. In this study all of the non-edible offal components were significantly affected $(\mathrm{P}<0.001)$ by diet.

Among the supplemented groups, the weight of penis, skin, lung with trachea, pancreas, bladder, full gut and total non-edible offal (TNEOC) were significantly higher in T4 than in T2 and T3. The weight of head without tongue and skin were significantly $(\mathrm{P}<0.001)$ lower in $\mathrm{T} 3$ than in $\mathrm{T} 4$ and $\mathrm{T}$. In line with the present study, [51] reported that gut content of lambs fed different roughage to concentrate ratio was similar between all the treatment groups.

\subsection{Partial Budget Analysis}

The cost of feeds used in the experiment and the result of partial budget analysis is shown in Table 9. The result of partial budget analysis revealed that the high

Table 8. Non-edible offal components of Local sheep fed on hay based diet and supplement with groundnut haulms and maize bran mix in Assosa district.

\begin{tabular}{|c|c|c|c|c|c|c|}
\hline Parameter & $\mathrm{T} 1$ & $\mathrm{~T} 2$ & $\mathrm{~T} 3$ & $\mathrm{~T} 4$ & SEM & SL \\
\hline Head without tongues (gm) & $1544.0^{c}$ & $15689.0^{\mathrm{b}}$ & $1577^{\mathrm{a}}$ & $1581.0^{\mathrm{a}}$ & 2.0 & $* * *$ \\
\hline skin(gm) & $1804.0^{\mathrm{d}}$ & $1955.0^{c}$ & $1985^{\mathrm{b}}$ & $1999.0^{\mathrm{a}}$ & 0.6 & $* * *$ \\
\hline Lung with trachea (gm) & $481.3^{\mathrm{c}}$ & $485.2^{\mathrm{b}}$ & $486.2^{\mathrm{b}}$ & $488.2^{\mathrm{a}}$ & 0.4 & $* * *$ \\
\hline Pancreas (gm) & $64.3^{c}$ & $65.2^{\mathrm{b}}$ & $66.0^{\mathrm{b}}$ & $66.8^{\mathrm{a}}$ & 0.1 & $* * *$ \\
\hline Spleen (gm) & 61.0 & 62.0 & 63.0 & 64.0 & 0.3 & NS \\
\hline Bladder (gm) & $33.0^{c}$ & $33.5^{\mathrm{bc}}$ & $34.0^{\mathrm{b}}$ & $35.0^{\mathrm{a}}$ & 0.13 & $* * *$ \\
\hline Gallbladder (gm) & $15.3^{\mathrm{c}}$ & $16.0^{\mathrm{bc}}$ & $16.3^{\mathrm{b}}$ & $17.0^{\mathrm{a}}$ & 0.1 & $* * *$ \\
\hline Full gut(gm) & $3917.0^{c}$ & $4022.0^{\mathrm{b}}$ & $4065.0^{\mathrm{b}}$ & $4203.0^{\mathrm{a}}$ & 21.3 & $* * *$ \\
\hline Penis (gm) & $60.8^{c}$ & $62^{\mathrm{b}}$ & $63.0^{\mathrm{b}}$ & $64.0^{\mathrm{a}}$ & 0.3 & $* * *$ \\
\hline Feet with hooves (gm) & $663.3^{c}$ & $678^{\mathrm{b}}$ & $679.0^{\mathrm{ab}}$ & $682.0^{\mathrm{a}}$ & 0.8 & $* * *$ \\
\hline TNEOC $(\mathrm{kg})$ & $8.0^{c}$ & $8.9^{\mathrm{b}}$ & $9.03^{\mathrm{b}}$ & $9.2^{\mathrm{a}}$ & 0.02 & $* * *$ \\
\hline
\end{tabular}


Table 9. Partial budget analysis of Local sheep fed on hay based diet and supplement with groundnut haulms and maize bran mix.

\begin{tabular}{|c|c|c|c|c|}
\hline Parameter & $\mathrm{T} 1$ & $\mathrm{~T} 2$ & T3 & $\mathrm{T} 4$ \\
\hline Number of animals & 6 & 6 & 6 & 6 \\
\hline Total Purchase price of sheep (ETB) & $13,800.0$ & $13,800.0$ & $13,800.0$ & $13,800.0$ \\
\hline Total basal diet intake $(\mathrm{kg})$ & 334.8 & 342.2 & 342.2 & 343.9 \\
\hline Total maize bran consumed $(\mathrm{kg})$ & & 148.1 & & \\
\hline Total concentrate mix consumed (kg) & & & 148.6 & \\
\hline Total Groundnut haulms consumed (kg) & & & & 147.7 \\
\hline Cost of GH consumed (ETB) & 0.0 & 0.0 & 0.0 & 296.0 \\
\hline Cost of maize bran consumed (ETB) & 0.0 & 592.3 & 0.0 & 0.0 \\
\hline Cost of concentrate mix consumed (ETB) & 0.0 & 0.0 & 338.2 & \\
\hline $\begin{array}{l}\text { Total cost of supplementary } \\
\text { feed consumed (ETB) }\end{array}$ & & 592.3 & 338.2 & 296.0 \\
\hline Cost of basal diet (ETB) & 133.9 & 136.9 & 136.9 & 137.6 \\
\hline Selling price of sheep (ETB) & $16,800.0$ & $19,200.0$ & $19,800.0$ & $20,700.0$ \\
\hline Total variable cost & 133.9 & 729.2 & 475.1 & 433.6 \\
\hline Total return & 3000.0 & 5400 & 6000.0 & 6900 \\
\hline Change in total return ( $\triangle \mathrm{TR}$ in $\mathrm{ETB})$ & & 1200 & 1800.0 & 2700.0 \\
\hline Net return & 2866.1 & 4670 & 5524.9 & 6666.0 \\
\hline Change in net return $(\triangle \mathrm{NR}$ in $\mathrm{ETB})$ & & 604 & 1458.9 & 2600.4 \\
\hline Change in total variable cost ( $\triangle \mathrm{TVC}$ in ETB) & & 595.3 & 341.2 & 99.7 \\
\hline Marginal rate of return $\%(\Delta \mathrm{NR} / \Delta \mathrm{TVC})$ & & 101.5 & 427.6 & 2608.2 \\
\hline
\end{tabular}

level of CP\% in groundnut haulms (T4) resulted in higher profit margin than other treatments. Yearling local sheep fed natural grass hay basal diet had lower net return and the supplemented group recorded the highest net return.

The results suggested that supplementation of natural grass hay basal diet with groundnut haulms was more profitable than supplemented with concentrated mix and maize bran. The net return from the supplemented experimental treatments was 4670.0, 5525.0 and 6666.0 ETB per treatment for T2, T3 and T4, respectively. The difference in net return was in a similar trend with their weight gain. The higher net return in T4 was due to the quality of protein and the lower ADL (8.21) contained in groundnut haulms supplementation, which resulted in higher body weight gain $(156.2 \mathrm{~g} / \mathrm{day} / \mathrm{sheep})$ as compared to the other treatments that had ADG of $46.4 \mathrm{~g}, 103.2 \mathrm{~g}$ and $123.7 \mathrm{~g}$ for T1, T2 and T3, respectively. This indicates that yearling local sheep fed with better quality feed perform well and have higher body weight gain and sold at maximum price and earn better net. The result of this study is in agreement with the report of [48], 
who indicated good economic return as a result of supplementation.

The difference in the net return among treatments might be with increasing ADG due to the high $\mathrm{CP}$ and low ADL contents and better protein quality in groundnut haulms that improved feed utilization efficiency of yearling local sheep. Marginal rate of return showed each additional unit of ETB per sheep cost increment resulted in 101.5, 427.6 and 2608.0 ETB benefit for T2, T3, and T4, respectively. Generally, local sheep that have a better nutrient intake had superior ADG, as a result of which they fetched higher sale price, and earn higher net return. The difference in the control and treatment was due to the difference in live weight change of the yearling local sheep in each treatment, which was a function of differences in feed quality and feed conversion efficiency.

\section{Conclusions and Recommendations}

This experiment was conducted to evaluate the effects of groundnut haulms, maize bran and their mix supplementation on local sheep meat production performance in Assosa District. Twenty-four intact male local sheep were used in the feeding trial. A randomized complete block design (RCBD) was used to conduct the feeding trial with four treatments namely, ad libitum feeding of natural grass hay plus 0 (T1, control), and 300, 300 and $300 \mathrm{~g}$ DM per head per day of $100 \%$ maize bran, $50 \%$ maize bran and $50 \%$ groundnut haulm and $100 \%$ groundnut haulm for T2, T3 and T4, respectively. The chemical analyses results of the supplements showed that groundnut haulm was high in CP content. The feed intake and digestibility in sheep supplemented with groundnut haulms (T4) was higher than in other treatments. A superior daily live weight gain was recorded in yearling local sheep supplemented with groundnut haulms (156.2 g) followed by concentrate mix (123.7 g) and maize bran (103.3 g). However, the lower averages daily gain $(46.4 \mathrm{~g} / \mathrm{d}$ ) was recorded in the control group (T1). Feed conversion efficiency was $0.08,0.11,0.14$ and 0.17 , respectively for T1, T2, T3 and T4, respectively. Similarly, slaughter weight, empty body weight, hot carcass weight and dressing percentage on a slaughter weight basis were higher in the supplemented sheep groups as compared to the control group. The mean rib eye muscle area significantly differs among treatments $\left(9.7,11.1,11.6\right.$ and $12.5 \mathrm{~cm}^{2}$ for T1, T2, T3 and T4, respectively). The results of this study showed that there was a significant difference $(\mathrm{P}<0.001)$ in most of the edible and non-edible offal components of sheep. Hence, $300 \mathrm{~g}$ per day per head of groundnut haulms, concentrated mix and maize bran could be recommended in that order to supplement intact local sheep fed a basal diet of hay for improved feed intake, growth and carcass characteristics and hence high economic returns achievement.

Based on the study results, the following recommendations were made for further research and development interventions:

* The CP content of groundnut haulms and concentrated mix was comparable with other protein source feed; and has a favorable response in terms of sheep feed intake, body weight improvement and net profit. Therefore, the 
use of groundnut haulms for other animal species should be studied to induct the promising feed development strategies.

* The use of maize bran, groundnut haulms and their mixture as supplemental feed generated promising result in on-station study. On-farm study is recommended using these supplements for sheep based on different basal for better utilization of low-quality feed resources and thereby increase performance of animals.

\section{Acknowledgements}

I wish to express my deep gratitude and appreciation to my research major advisor Dr. Befikadu Zewdie and co-advisor Dr. Hirut Yirga for their sustained guidance, encouragement and constructive comments at all stages of the thesis work and without his encouragement, insight and professional expertise the completion of this work would not have been possible. Many thanks also extended to Mr. Belay Teshome for feeding the animals, guarding and cleaning the pen. A special word of thanks goes to Mr. Habte who helped me in recording data.

\section{Conflicts of Interest}

The authors declare no conflicts of interest regarding the publication of this paper.

\section{References}

[1] Hu, T. and Desai, J.P. (2004) Soft-Tissue Material Properties under Large Deformation: Strain Rate Effect. Proceedings of the 26 th Annual International Conference of the IEEE EMBS, San Francisco, 1-5 September 2004, 2758-2761.

[2] Wit, E. and McClure, J. (2004) Statistics for Microarrays: Design, Analysis, and Inference. 5th Edition, John Wiley \& Sons Ltd., Chichester.

[3] Abraha, L. (2013) Effects of Intercropping Maize with Cowpea and Lablab on Sheep Growth Performance in Raya District of Tigray Region, Ethiopia. Herald Journal of Agriculture and Food Science Research, 2, 98-108.

[4] Alfa, M., Aliyu, U., Eze, J.N., Jiya, E.Z. and Muhammad, I.G. (2016) Performance of Young Sheep Fed Maize Bran and Groundnut Hay Supplemented with Sodium Chloride. International Letters of Natural Sciences, 60, 52-58. https://doi.org/10.18052/www.scipress.com/ILNS.60.52

[5] Duguma, G., Mirkena, T., Haile, A., Iñiguez, L., Okeyo, A.M., Tibbo, M., et al. (2011) Identification of Smallholder Farmers and Pastoralists' Preferences for Sheep Breeding Traits: Choice Model Approach. Animal, 5, 1984-1992. https://doi.org/10.1017/S1751731111001029

[6] Mengesha, M. and Tsega, W. (2012) Indigenous Sheep Production in Ethiopia: A Review. Iranian Journal of Applied Animal Science, 2, 311-318.

[7] Tegegne, A., Hoekstra, D., Gebremedhin, B. and Berhe, K. (2011) Intensification of Crop-Livestock Farming Systems through Market-Orientation in Ethiopia. Development on the Margin, Tropentag, Bonn, 5-7 October 2011, 7-10.

[8] Befikadu, Z., Mengistu, U., Yosef, T. and Solomon, G. (2019) Arab Goat Husban- 
dry, Breeding Practices and Marketing Systems in Western Lowland of Ethiopia. Journal of East African Journal of Veterinary and Animal Sciences. (Unpublished)

[9] Singh, B.B., Musa, A., Ajeigbe, H.A. and Tarawali, S.A. (2011) Effect of Feeding Crop Residues of Different Cereals Andlegumes on Weight Gain of Yankassa Rams. International Journal of Livestock Production, 2, 17-23.

[10] Nurfeta, A. (2010) Digestibility and Nitrogen Utilization in Sheep fed Enset (Ensete ventricosum) Pseudostem or Corm and Graded Levels of Desmodium intortum Hay to Wheat Straw-Based Diets. Journal of Animal Physiology and Animal Nutrition, 94, 773-779. https://doi.org/10.1111/j.1439-0396.2009.00960.x

[11] Kosgey, I.S. and Okeyo, A.M. (2007) Genetic Improvement of Small Ruminants in Low-Input, Small-Holder Production Systems: Technical and Infrastructural Issues. Small Ruminant Research, 70, 76-88.

https://doi.org/10.1016/j.smallrumres.2007.01.007

[12] Wijnands, H.M., Biersteker, J. and Van Loo, E.N. (2009) Oil Seed Business Opportunity in Ethiopia 2009. Addis Ababa.

[13] Hailegiorgis, B. (2011) Export Performance of Oilseeds and Its Determinants in Ethiopia. Journal of Cereals and Oilseeds, 2, 1-15.

[14] Owuor, J.J. and Owuor, G. (2014) Evaluating the Marketing Opportunities for Soybean and Its Products in the East African Countries of ASARECA: Kenya Report. Research Journal of Agriculture and Environmental Management, 3, 477-484.

[15] Muhammad, I.R. (2008) Livestock Ownership and Unconventional Feed Resources from Refuse Dumps in Urban Metropolis of Semi-Arid Zone. Research Journal of Animal Sciences, 2, 12-16.

[16] Tayachew, A., Leta, S. and Derso, S. (2015) Prevalence of Donkey Trypanosomosis in Assosa District, Benishangul Gumuz Regional State, Northwest Ethiopia. Global Veterinaria, 6, 147-153.

[17] As ARC (Assosa Agricultural Research Center) (2011) Results of Farming System Survey Benishangul-Gumuz Regional State. Ethiopian Institute of Agricultural Research, Assosa Agricultural Research Center, Ethiopia. (Unpublished)

[18] McDonald, P., Edwards, R.A., Greenhalgh, J.F.D., Morgan, C.A., Sinclair, L.A. and Wilkinson, R.G. (2010) Animal Nutrition. 7th Edition, Prentice Hall, Harlow, London, 714.

[19] Purchas, R.W. (1978) Some Effects of Nutrition and Castration on Meat Production from Male Suffolk Crosses Lambs. Journal of Agricultural Research, 21, 367-376.

[20] AOAC (Association of Official Analytical Chemists) (1990) Official Method of Analysis. 15th Edition, AOAC Inc., Arlington, 1298.

[21] Van Soest, P.J. and Robertson, J.B. (1985) Methods of Analysis of Dietary Neutral Detergent Fiber and Non Starch Polysaccharides in Relation to Animal Nutrition. Journal of Dairy Science, 74, 3585-3597. https://doi.org/10.3168/jds.S0022-0302(91)78551-2

[22] Upton, M. (1979) Farm Management in Africa: The Principle of Production and Planning. Oxford University Press, Oxford, 282-298.

[23] Van Soest, P.J. (1994) Nutritional Ecology of Ruminants. 2nd Edition, Cornell University Press, Ithaca, London, 476. https://doi.org/10.7591/9781501732355

[24] Getnet, M. (2019) Effect of Feeding Either Soybean or Groundnut Straw as Basal Diet on Feed Intake and Nutrient Utilization of Gumuz Sheep. Veterinary Science and Research, 6, Article No. 46. https://www.researchgate.net/publication/34250047

[25] Aschalew, A. and Getachew, A. (2013) Supplementation of Raw, Malted and Heat 
Treated Grass Pea (Lathyrus sativus) Grain on Body Weight Gain and Carcass Characteristics of Farta Sheep. International Journal of Soil and Crop Sciences, 1, 16.

[26] Negussie, M. (2008) Effects of Supplementation of Napier Grass with Greenleaf Desmodium or Lablab on Feed Intake, Digestibility and Live Weight Change of Washera sheep. MSc. Thesis Presented to the School of Graduate Studies of Alemaya University of Agriculture, Haramaya, 85 p.

[27] Taye, B. (2004) Effects of Days of Harvesting on Yield, Chemical Composition, and in Vitro Organic Matter Digestibility of Pennisetum purpureum Sole or Intercropped with Desmodium intortum or Lablab purpureus. MSc. Thesis Presented to the School of Graduate Studies of Alemaya University of Agriculture, Haramaya, 79 p.

[28] Tessema, Z. (2000) Productivity, Chemical Composition and Digestibility of Elephant Grass (Pennisetum purpureum) as Influenced by Height of Harvest and Different Sources of Fertilizer Application. MSc. Thesis Presented to the School of Graduate Studies of Alemaya University of Agriculture, Haramaya, 67 p.

[29] Topps, J.H. (1997) Forage Legumes as Protein Supplement to Poor Quality Diets in the Semi-Arid Tropics. In: Wallace, R.J. and Lahlov-kassi, A., Eds., Rumen Ecology Research Planning. Proceeding of a Workshop Held at ILRI (International Livestock Research Institute), Addis Ababa, 13-18 March 1995, 45-50.

[30] Biru, K. (2008) Effects of Supplementation with Sweet Potato Tuber and Haricot Bean Screenings on Feed Utilization, Growth and Carcass Characteristics of Adilo Sheep. MSc. Thesis, Alemaya University of Agriculture, Alemaya, 87 p.

[31] Yenesew, A. (2010) Assessment of Small Ruminant Production Systems and On-Farm Evaluation of Urea Treated Wheat Straw and Concentrate Feeding on Sheep Body Weight Change, in Burie Woreda, West Gojjam. M.Sc. Thesis, Haramaya University, Haramaya, 134 p.

[32] Awet, E. (2007) Feed Utilization, Body Weight Change, and Carcass Characteristics of Intact and Castrated Afar Sheep Fed Urea Treated Teff Straw Supplemented with Graded Levels of Wheat Bran. M.Sc. Thesis, Alemaya University, Ethiopia.

[33] Fentie, B. (2007) Effect of Supplementation of Hay with Noug Seed (Guizotia abyssinica) Cake, Wheat Bran and Their Mixtures on Feed Utilization, Digestibility and Live Weight Change in Farta sheep. MSc. Thesis Presented to the School of Graduate Studies of Alemaya University of Agriculture, Alemaya, $87 \mathrm{p}$.

[34] Fernandez-Rivera, A.S. and Dan-Gomma, A. (2008) Sheep Fattening with Groundnut Haulms and Millet Bran in the West African Sahel. Revue délevage et de Médecine Vétérinaire des Pays Tropicaux, 61, 215-220.

https://doi.org/10.19182/remvt.9992

[35] Mulu, M., Berhan, T. and Alemu, Y. (2008) The Effect Supplementation of Grass Hay with Different Levels of Brewery Dried Grain on Feed Intake Digestibility and Body Weight Gain in Intact Wogera Lambs. East Africa Journal of Sciences, 2, 105-110. https://doi.org/10.4314/eajsci.v2i2.40338

[36] Solomon, M. and Simret, B. (2008) Bodyweight and Carcass Characteristics of Somali Goats Fed Hay Supplemented with Graded Levels of Peanut Cake and Wheat Bran Mixture. Tropical Animal Health and Production, 40, 553-560. https://doi.org/10.1007/s11250-008-9133-6

[37] Abebe, H., Solomon, M., Berhan, T. and Asaminew, T. (2011) Body Weight and Carcass Characteristics of Washera Sheep Fed Urea Treated Rice Straw Supplemented with Graded Levels of Concentrate Mix. Livestock Research for Rural De- 
velopment, 23, 50-61.

[38] Bimrew, A. (2008) Supplementation of Different Levels of Rice Bran and Noug Seed (Guizotia abissynica) Cake Mixtures on Nutrient Utilization of Farta Sheep Fed Natural Pasture Hay. MSc. Thesis, Alemaya University of Agriculture, Alemaya.

[39] Abebaw, N. (2007) Effects of Rice Bran and/or Noug Seed (Guizotia abyssinica) Cake Supplementation on Feed Utilization and Live Weight Change of Farta Sheep Fed Native Grass Hay. MSc. Thesis, Haramaya University, Haramaya, 94 p.

[40] Kaitho, R.J. and Kariuki, J.N. (1998) Effects of Desmodium, Sesbania and Calliandra Supplementation on Growth of Dairy Heifers Fed Napier Grass Basal Diet. AsianAustralasian Journal of Animal Sciences, 11, 680-684. https://doi.org/10.5713/ajas.1998.680

[41] Gebregiorgis, F., Negesse, T. and Nurfeta, A. (2009) Feed Intake and Utilization in Sheep Fed Graded Levels of Dried Moringa (Moringa stenopetala) Leaf as a Supplement to Rhodes Grass Hay. Tropical Animal Health and Production, 41, 511-517. https://doi.org/10.1007/s11250-011-9927-9

[42] Nsahalai, I.V. and Ummuna, N.N. (1996) Sesbania and Lablab Supplementation of Oat Hay Basal Diet Fed to Sheep with or without Maize Grain. Animal Feed Science and Technology, 61, 275-289. https://doi.org/10.1016/0377-8401(95)00941-8

[43] Kefelegn, K. and Gebremeskel, G. (2010) Statistical Modeling of Growth Performance Data on Sheep Using Mixed Linear Models. Livestock Research for Rural Development, 22, Article No. 80. http://www.lrrd.org/lrrd22/4/kefe22080.htm

[44] Yeshambel, M., Mengistu, U. and Getachew, A. (2012) Intake, Digestibility, Live Weight Changes and Rumen Parameters of Washera Sheep Fed Mixtures of Lowland Bamboo (Oxytenanthera abyssinica) Leaves and Natural Pasture Grass Hay at Different Ratios. Pakistan Journal of Nutrition, 11, 322-331. https://doi.org/10.3923/pjn.2012.322.331

[45] Abadi, N., Mohammed, Y. and Getachew, A. (2014) Substitution Effect of Faba Bean (Viciafaba L.) Hulls to Wheat Bran on Body Weight Change and Carcass Characteristics of Afar Sheep Fed Hay as Basal Diet. Agricultural Science, Engineering and Technology Research, 2, 1-11.

[46] Melese, G., Berhan, T. and Mengistu, U. (2014) Effect of Supplementation with Nonconventional Feeds on Feed Intake and Body Weight Change of Washera Sheep Fed Urea Treated Finger Millet Straw. Greener Journal of Agricultural Sciences, 4, 67-74. https://doi.org/10.15580/GJAS.2014.2.1202131003

[47] Hirut, Y., Solomon, M. and Mengistu, U. (2011) Effect of Concentrate Supplementation on Live Weight Change and Carcass Characteristics of Hararghe Highland Sheep Fed a Basal Diet of Urea-Treated Maize Stover. Livestock Research for Rural Development, 23, No. 12. http://www.lrrd.org/lrrd23/12/hiru23245.htm

[48] Fitwi, M. and Tadesse, G. (2013) Effect of Sesame Cake Supplementation on Feed Intake, Body Weight Gain, Feed Conversion Efficiency and Carcass Parameters in the Ration of Sheep Fed on Wheat Bran and Teff (Eragrostis teff) Straw. Momona Ethiopian Journal of Science, 5, 89-106. https://doi.org/10.4314/mejs.v5i1.85333

[49] Berhan, T. and Asnakew, A. (2015) Live Weight Gain and Carcass Yield Characteristics of Intact Male Hararghe Highland Goats Fed Varying Levels of Hay to Concentrate Ratios. Scholarly Journal of Agricultural Science, 5, 178-182.

[50] Yami, A. (2008) Chapter 7. Nutrition and Feeding of Sheep and Goats. Sheep and Goat Production System in Ethiopia. In: Yami, A. and Merkel, R.C., Eds., Sheep and Goat Production Handbook for Ethiopia, Brana Publishing House, Addis Ababa, 110-167. 
[51] Assefu, G. (2012) Comparative Feedlot Performance of Washera and Horro Sheep Fed Different Roughage to Concentrate Ratio. MSc. Thesis, Haramaya University, Haramaya, 68 p. 